\title{
KANDUNGAN ASAM LEMAK, ZINK, DAN COPPER PADA TEMPE, BAGAIMANA POTENSINYA UNTUK MENCEGAH PENYAKIT DEGENERATIF?
}

\author{
Diah M. Utari ${ }^{1}$ \\ 'Departemen Gizi Kesmas Fakultas Kesehatan Masyarakat, UI
}

\begin{abstract}
FATTY FOOD, ZINC, AND COPPER CONTENTS IN TEMPE, HOW ITS POTENTIAL TO PREVENT DEGENERATIF DISEASES?
\end{abstract}

Tempe is Indonesian traditional food that very popular, but its function has not been well informed by community. During the fermentation process, Rhizopus sp causes compositional changes in lipid, by hydrolysis more than one-third of fat of soybeans. The fatty acid composition that predominant in tempe composed by linoleic acid, oleic acid and linolenic acid. Tempe also contains minerals, namely $\mathrm{Zn}$ and $\mathrm{Cu}$, that have role in increasing SOD antioxidant enzyme activity. The role of the enzyme is as a first barrier to free radical. Tempe could be considered as functional food which have benefit for address of lipid profile and prevent free radical which may reduce degenerative disease risk. Although there are no dietary recommendation of tempe for individual, it may a great benefit to consume tempe about 2-3 slice/day (100$150 \mathrm{~g}$ ). It is better to cook with boiling or steaming to get maximal benefit of tempe for health.

Key words: traditional food, tempe, fermentation

\section{PENDAHULUAN}

$\mathrm{T}$ empe adalah pangan tradisional khas Indonesia yang berasal dari kedelai dan sangat popular di Indonesia. Tempe dipasarkan secara luas baik di pasar tradisional maupun pasar modern, dan dikonsumsi lebih dari separuh penduduk. Karena harganya yang murah maka tempe dijadikan lauk utama khususnya bagi masyarakat dengan pendapatan rendah. Hal tersebut yang menyebabkan nilai sosial tempe dianggap rendah.

Jika melihat hubungan perkembangan ekonomi dan penyakit maka Indonesia merupakan negara berkembang dengan pertumbuhan ekonomi yang semakin meningkat sehingga membawa konsekuensi perubahan gaya hidup termasuk kebiasaan makan dan rendahnya aktivitas fisik. Hal tersebut mengakibatkan terjadinya perubahan penyakit yang dahulu didominasi penyakit menular ke penyakit tidak menular atau sering disebut sebagai penyakit degeneratif, misalnya: atherosklerosis, stroke, hipertensi, diabetes mellitus dan penyakit jantung. Ketidaktahuan mengenai gizi khususnya pada makanan yang sebaiknya dikonsumsi dan didorong dengan menjamurnya makanan siap saji yang cenderung tinggi lemak jenuh namun rendah serat, vitamin dan mineral merupakan faktor pencetus adanya perubahan pola penyakit tersebut.

Penelitian yang telah dilakukan lebih dari 60 tahun terakhir menunjukkan bahwa mengganti konsumsi hewani dengan kedelai dapat menurunkan hiperlipoproteinemia dan atherosklerosis. Dalam 10 tahun terakhir penelitian tentang hal tersebut semakin meningkat dan mendalam, dan membuktikan bahwa konsumsi kedelai tidak saja memperbaiki beberapa aspek kesehatan tetapi juga memperbaiki kesehatan jantung. Mengganti makanan tinggi lemak jenuh, lemak trans dan kolesterol dengan kedelai akan membawa efek menguntungkan pada faktor risiko penyakit jantung koroner seperti hiperlipidemia, hipertensi, hiperglikemia. Selain itu kedelai juga berperan sebagai antioksidan yang potensial.

Data epidemiologi selama berpuluh tahun menunjukkan bahwa masyarakat di wilayah Asia merupakan masyarakat pengonsumsi kedelai terbesar di dunia, jauh lebih tinggi dibanding di wilayah barat. Konsumsi kedelai di Jepang diperkirakan lebih dari $50 \mathrm{~g} / \mathrm{hari}$ sementara di Amerika Serikat kurang dari 5 g/hari. Pola konsumsi tersebut berpengaruh pada pola penyakit, seperti misalnya penyakit jantung koroner (PJK).

Pada tahun 1998, kematian karena PJK per 100.000 penduduk usia 35 hingga 74 tahun sebesar 401 pada laki-laki di Amerika Serikat, 
201 pada laki-laki Jepang, 197 pada wanita Amerika Serikat dan 99 pada wanita Jepang. ${ }^{1}$

Indonesia termasuk salah satu negara pengonsumsi kedelai yang cukup besar, meskipun masih lebih rendah dibanding Jepang, di mana kebutuhan kedelai di Indonesia mencapai 2.4 juta ton per tahun. Kurang lebih separuh dari kedelai tersebut diolah menjadi tempe, dan diperkirakan konsumsi kedelai mencapai $25 \mathrm{~g} / \mathrm{hr} / \mathrm{kapita.}^{2}$

Hasil Riskesdas 2007 menyebutkan bahwa penyebab kematian tertinggi pada dewasa umumnya didominasi oleh penyakit degeneratif dengan stroke pada posisi pertama diikuti hipertensi, diabetes mellitus dan penyakit jantung. ${ }^{3}$ Faktor risiko penyakit tersebut terdiri dari dua faktor yaitu faktor lipid: tingginya kadar kolesterol total (K-total), kolesterol LDL (K-LDL), trigliserida, dan rendahnya kolesterol HDL (K$\mathrm{HDL}$ ) serta faktor non lipid meliputi hipertensi, obesitas, merokok, aktivitas fisik, stress dan obat.

Tempe dipilih sebagai subyek penelitian dengan beberapa pertimbangan, yaitu kedelai sangat mudah diperoleh dipasaran dan mudah diolah menjadi tempe sehingga pasokan tempe tidak akan habis di pasaran. Tempe juga relatif mudah dipasarkan serta secara ekonomi terjangkau bagi pembeli dan menguntungkan bagi pedagang. Di tingkat rumah tangga, tempe sangat mudah diolah menjadi berbagai jenis masakan.

Saat ini tempe juga dipertimbangkan sebagai pangan fungsional (functional food) karena kandungan gizi dan substansi aktifnya yang bermanfaat bagi kesehatan. Sebagai pangan tradisional, tempe mempunyai komposisi gizi yang jauh lebih baik dibanding kedelai. Namun demikian, konsumsi tempe per kapita di Indonesia masih belum tergolong tinggi. Salah satu penyebab masih rendahnya konsumsi tempe adalah karena ketidaktahuan sebagian besar masyarakat mengenai kandungan gizi dan komponen aktif pada tempe serta manfaatnya bagi kesehatan. Sementara itu di sisi lain, justru terjadi peningkatan konsumsi tempe di hampir semua negara di dunia, hal ini berkaitan dengan semakin meningkatnya pemahaman mengenai hidup sehat dan semakin meningkatnya penganut vegetarian, yang mengonsumsi tempe sebagai pengganti daging. Mengingat hal tersebut perlu kiranya dikaji kembali peran berbagai jenis zat gizi dalam tempe. Penelitian ini bertujuan menganalisis kandungan lemak dan asam lemak serta mineral zink dan copper dalam tempe dan mengkajinya sebagai makanan yang bermanfaat bagi kesehatan.

\section{METODE PENELITIAN}

Bahan yang mengandung lemak dihidrolisis menjadi asam lemak, selanjutnya ditransformasi menjadi bentuk ester yang bersifat lebih mudah menguap. Transformasi dilakukan dengan cara metilasi sehingga diperoleh bentuk metal ester asam lemak (FAME), yang akan dianalisis dengan alat kromatografi gas. Secara lebih rinci analisis dibagi menjadi dua tahap yaitu preparasi contoh (hidrolisis) dan analisis asam lemak sebagai FAME. ${ }^{4}$

Tahap hidrolisis dimulai dengan menimbang bahan sebanyak $20-30 \mathrm{mg}$ dalam

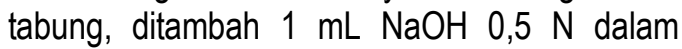
methanol dan dipanaskan dalam penangas selama 20 menit (mt). Setelah itu ditambah 2 $\mathrm{mL}$ BP3 $16 \%$ dan $5 \mathrm{mg} / \mathrm{mL}$ standar internal, dipanaskan selama $20 \mathrm{mt}$. Setelah dingin ditambahkan $2 \mathrm{~mL} \mathrm{NaCl}$ jenuh dan $1 \mathrm{~mL}$ heksana, dan dikocok hingga tercampur. Pindahkan lapisan heksana dengan pipet tetes dalam tabung yang telah berisi $0,1 \mathrm{~g} \mathrm{Na}_{2} \mathrm{SO}_{4}$ anhidrat, dibiarkan $15 \mathrm{mt}$. Pisahkan fase cair dan diinjeksi ke kromatografi gas.

Tahap analisis asam lemak. Pelarut sebanyak $1 \mu$ l dinjeksi ke dalam kolom. Puncak pelarut akan nampak sekitar 1 menit kemudian. Setelah pena kembali ke nol, sebanyak $5 \mu \mathrm{l}$ campuran standar FAME diinjeksi. Jika semua puncak telah keluar, injeksikan $5 \mu \mathrm{l}$ larutan contoh yang telah disiapkan sebelumnya. Ukur waktu retensi dan puncak masing-masing komponen. Bandingkan waktu retensi dengan standar untuk mendapatkan hasil jenis dari komponen dalam contoh.

Pemeriksaan $\mathrm{Zn}$ dan $\mathrm{Cu}$ menggunakan spektrofotometer serapan atom (AAS). ${ }^{4}$ Preparasi contoh dilakukan dengan menimbang tempe sebanyak $2 \mathrm{~g}$, dimasukkan ke dalam cawan porselen dan dipanaskan dalam bunner api hingga zat organik menguap sebanyak mungkin (sampai tidak berasap lagi). Cawan dipindahkan ke tanur dan dipanaskan pada suhu $300^{\circ} \mathrm{C}$ hingga sampel berwarna keabuan. suhu dinaikkan pada $550^{\circ} \mathrm{C}$ selama 4 jam. Setelah itu cawan dikeluarkan, dan dinginkan 
serta ditambahkan $\mathrm{HCl} 3 \mathrm{~N}$ panas. Cairan dimasukkan ke dalam labu takar $50 \mathrm{ml}$ (cawan dibilas dengan air bebas ion berulang-ulang dan dimasukkan dalam labu takar) dan ditambahkan air bebas ion hingga tanda tera, dikocok, disaring dengan kertas saring whatman no. 41. Selanjutnya siap dianalisis.

\section{HASIL DAN BAHASAN}

\section{Kadar Lemak dan Asam Lemak Tempe}

Hasil analisis lemak dan asam lemak tempe pada penelitian ini menunjukkan bahwa tempe mengandung $2,89 \mathrm{~g}$ lemak. Kandungan lemak tempe jauh di bawah kandungan lemak hewani dengan kadar protein yang hampir sama dengan tempe. Ikan mas, misalnya, mempunyai kadar lemak 5,8 g dan protein 18,3 g, sementara tempe dengan kandungan lemak jauh dibawah ikan mas, namun mempunyai kandungan protein yang hampir sama yaitu 16,9 g. Sedangkan telur ayam mempunyai kandungan lemak yang jauh lebih tinggi $(10,8 \mathrm{~g})$ dibanding tempe namun proteinnya jauh lebih rendah $(12,4 \mathrm{~g}) .^{5}$

Asam lemak yang dominan adalah linoleic acid sebesar 50,12\%w/w, disusul oleic acid, linolenic acid dan palmitic acid. Semuanya tergolong asam lemak tidak jenuh rantai panjang, sekitar $80 \%$ dari total asam lemak. ${ }^{6}$ Asam lemak yang dominan tersebut tergolong esensial yaitu tidak dapat disintesa di dalam tubuh sehingga harus diperoleh dari konsumsi makanan.

Hasil analisis asam lemak dalam penelitian ini sejalan dengan penelitian terdahulu, dimana asam lemak tertinggi pada tempe adalah linoleic acid disusul oleic acid dan linolenic acid, ${ }^{7,8}$ namun tidak sejalan dengan penelitian lain dimana kadar asam lemak tertinggi adalah oleic acid, sementara linolenic acid dan linoleic acid justru mengalami penurunan dibanding kedelai. ${ }^{9}$

Tabel 1

Kandungan lemak dan asam lemak per $100 \mathrm{~g}$ tempe kukus

\begin{tabular}{llc}
\hline Parameter & & Hasil \\
\hline Lemak & & $2,89 \mathrm{~g}$ \\
Asam Lemak & & \\
- Palmitic acid & C16:0 & $7,21 \mathrm{~g}$ \\
-Stearic acid & C18:0 & $3,05 \mathrm{~g}$ \\
- Oleic acid & C18:1n9c & $14,74 \mathrm{~g}$ \\
- Linoleic acid & C18:2n6c & $50,12 \mathrm{~g}$ \\
-Arachidic acid & C20:0 & $0,21 \mathrm{~g}$ \\
- Linolenic acid & C18:3n3 & $9,32 \mathrm{~g}$ \\
-Behenic acid & C22:0 & $0,22 \mathrm{~g}$ \\
\hline Seng & & $1.74 \mathrm{ppm}$ \\
Cu & & $1.69 \mathrm{ppm}$ \\
\hline
\end{tabular}

Kadar lemak pada kedelai rebus dan tempe sebenarnya relatif tidak terlalu berbeda, namun saat proses fermentasi terbentuk enzim lipase pada tempe yang menghidrolisis sebagian lemak kedelai dan meningkatkan 30 persen, ${ }^{10}$ atau 50-70 kali asam lemak bebas dibanding bentuk kedelai, ${ }^{11,12}$ serta menurunkan gliserida dari 22.3 persen menjadi 11.5 persen. ${ }^{13}$ Komposisi perubahan asam lemak disebabkan karena keberadaan dan aktivitas ragi dan bakteri serta lamanya fermentasi. ${ }^{14}$ Lipase yang dihasilkan saat fermentasi akan menghidrolisis lemak pada waktu fermentasi berlangsung, dengan laju tertinggi setelah 12 jam hingga 24 jam. Sementara asam lemak mencapai puncaknya setelah 36 jam fermentasi. Pelepasan asam lemak akan digunakan sebagai sumber karbon bagi R.oligosporus untuk asimilasi. ${ }^{12}$ Penelitian lain mengungkapkan bahwa lipase meningkatkan asam lemak bebas dari 0,5 persen saat perebusan kedelai menjadi 21 persen setelah menjadi tempe. ${ }^{15}$ Besarnya asam lemak yang dibebaskan tergantung dari komposisi inokulum yang digunakan. ${ }^{8}$ Hasil indentifikasi terlihat bahwa oleic, linoleic, linolenic, palmitic, dan stearic merupakan asam lemak yang paling banyak dibebaskan. ${ }^{10}$ Penelitian terdahulu juga 
menunjukkan bahwa minyak yang berasal dari tempe mempunyai daya tahan yang kuat terhadap peroksida lemak saat penyimpanan dalam suhu kamar, bahkan tidak berubah kadarnya ketika disimpan sekitar dua tahun, hal ini berbeda dengan minyak dari kedelai yang cenderung rentan terhadap peroksida saat penyimpanan. ${ }^{16}$

Secara organoleptik, tempe yang nikmat adalah setelah mengalami fermentasi sekitar 30 jam, karena rasa netral dan bau yang tidak menyengat, selain itu juga kandungan gizi termasuk asam lemak berada pada kondisi maksimal. Untuk mempertahankan organoleptik dan gizi yang baik, maka perlu pemasakan yang benar. Tempe yang digoreng akan mengalami penurunan asam lemak bebas seperti oleic acid, linoleic acid dan linolenic acid, namun justru meningkatkan caprilic acid, capric acid, lauric acid dan myristic acid yang manfaat kesehatannya tidak sebesar asam lemak yang mengalami penurunan. Saat penggorengan juga terjadi penambahan persentase gliserida pada tempe karena adanya absorbsi lemak dari minyak goreng, ${ }^{17}$ oleh sebab itu untuk mencapai manfaat tempe yang maksimal, sebaiknya dihindari pemasakan dengan menggoreng. Pengukusan atau perebusan dalam waktu singkat sekitar 10 menit sangat disarankan untuk mempertahankan semua zat gizi tempe. Mengonsumsi tempe mentah sebenarnya adalah cara yang paling baik dan menyehatkan meskipun tidak lazim dilakukan, bagaimanapun sebenarnya tempe mentah adalah bahan yang telah matang karena telah mengalami perebusan kedelai sebelum masuk pada fase fermentasi.

Hasil analisis studi ini menunjukkan bahwa kandungan Seng ( $\mathrm{Zn}$ ) pada tempe sebesar 1,74 ppm, hampir sama dengan kandungan Zn pada ayam (1,8 ppm). Selama proses fermentasi kedelai terjadi peningkatan bioavailability $\mathrm{Zn}$ dari 73 persen menjadi 84,5 persen. ${ }^{18}$ Tempe dapat dijadikan sumber $\mathrm{Zn}$ yang baik selain sumber hewani yang harganya relatif mahal. Sehingga dari sisi ekonomi, mengonsumsi tempe lebih menguntungkan dibanding pangan hewani.

\section{Manfaat Asam Lemak Tempe bagi Kesehatan}

Manfaat tempe bagi kesehatan sebenarnya tidak perlu diragukan lagi. Efek antioksidan pada tempe sebenarnya merupakan hasil dari efek sinergis tocopherol atau vitamin $E$ pada kedelai dengan asam amino yang dibebaskan selama fermentasi oleh Rhizopus oligosporus yang mengakibatkan timbulnya aktivitas lipase sehingga kadar asam lemak bebas pada tempe lebih tinggi dibanding kedelai. Potensi tempe untuk mencegah oksidasi lipid juga lebih besar dibanding tocopherol. ${ }^{19}$

Oleic acid. Oleic acid adalah asam lemak bebas kedua terbanyak pada tempe setelah linoleic acid. Oleic acid tergolong lemak bebas cis yang bermanfaat bagi tubuh yang jika dikonsumsi sebagai pengganti lemak jenuh (SAFA) akan menurunkan kolesterol darah. Meskipun efek hipokolesterolemia lebih rendah dibanding linoleic acid maupun linolenic acid namun demikian oleic acid punya kemampuan untuk meningkatkan Kholesterol (K) $-\mathrm{HDL}$ merupakan lemak baik yang dapat menurunkan risiko penyakit jantung, sehingga oleic acid sering diklaim untuk mencegah penyakit jantung. ${ }^{20}$

Linoleic acid. Seperti telah disebut di awal, asam lemak utama pada tempe adalah linoleic acid, secara spesifik dapat dijelaskan bahwa linoleic acid (18:2 $\omega-6)$ bersifat meningkatkan KHDL dan menurunkan K-LDL, hal ini berbeda dengan peran asam lemak lainnya yang cenderung bersifat hiperlipidemia. Jika konsumsi energi dari SAFA diganti oleh linoleic acid, maka secara bermakna akan menurunkan kolesterol darah. ${ }^{20}$

Linolenic acid adalah asam lemak bebas ketiga terbanyak dalam tempe. Asam lemak ini dapat lebih efektif menurunkan trigliserida darah dibanding asam linoleic. Namun harus lebih hati-hati dalam mengonsumsi karena jika dikonsumsi terlalu tinggi pada individu yang kadar K-LDL awalnya tinggi justru akan semakin meningkatkan kadar K-LDL awal serta menurunkan kadar K-HDL. Selama ini sumber linolenic acid yang popular adalah minyak ikan dan konsumsi dalam dosis tinggi pada orang yang rentan harus dalam pengawasan dokter. Keuntungan dari tempe adalah karena linolenic acid bukan asam lemak bebas utama, sehingga lebih leluasa untuk dikonsumsi dalam jumlah banyak tanpa mengurangi manfaatnya.

Peran lain dari linoleic dan linolenic acid adalah: 1) untuk kekuatan membran sel dan mencegah kerusakan jaringan kulit, 2) membantu transport dan metabolism kolesterol sehingga dapat menurunkan kadar kolesterol 
darah, 3) mengatur produksi enzim yang dibutuhkan untuk sintesa asam lemak non esensial dalam hati, 4) meningkatkan imunitas dan mencegah kerentanan terhadap infeksi, 5) merupakan precursor komponen aktif prostaglandin yang dibutuhkan dalam semua jaringan tubuh dan aktivitasnya mempengaruhi tekanan darah, pembekuan darah dan fungsi jantung. ${ }^{21}$

Elogasi dan desaturasi. Di dalam tubuh, linoleic acid dan linolenic acid tidak hanya dibutuhkan untuk semua membran sel tetapi juga mengalami elongasi dan desaturasi menjadi rantai yang lebih panjang dan merupakan precursor komponen eicosanoid yang menyerupai hormone, prostaglandin dan leukotrienes. Linoleic acid akan dikonversi menjadi arachidonic acid sementara linolenic akan dikonversi menjadi eicosapentaenoic acid (EPA) dan decosahexaenoic acid (DHA). ${ }^{20}$ EPA dan DHA dapat mencegah timbulnya platelet darah. Platelet dalam darah dalam jumlah besar akan mengganggu aliran darah yang merupakan faktor utama penyebab serangan jantung dan stroke. EPA dan DHA juga dapat memperbaiki trigliserida darah pada individu dengan hipertrigliserida.

Tabel 2

Pengaruh kandungan lemak pada makanan terhadap kadar lipoprotein darah

\begin{tabular}{lccccc}
\hline Faktor Gizi & & VLDL & LDL & HDL & Catatan \\
\hline Obesitas & & $\uparrow$ & $\uparrow$ & $\downarrow$ & \\
\hline SAFA & & & & & \\
- Lauric acid & $12: 0$ & - & $\uparrow$ & $\uparrow$ & \\
- Mytistic acid & $14: 0$ & - & $\uparrow \uparrow$ & $\uparrow$ & \\
- Palmitic acid & $16: 0$ & - & $\uparrow \uparrow$ & $\uparrow$ & \\
- Stearic acid & $18: 0$ & - & - & - & \\
\hline MUFA & & & & & \\
- Oleic acid & $18: 1$ cis & - & $\downarrow$ & $\uparrow$ & \\
- Elaidic acid & $18: 1$ trans & - & $\uparrow \uparrow$ & $\downarrow$ & \\
\hline PUFA $(\omega-6)$ & & & & & $\downarrow$ HDL jika konsumsi \\
- Linoleic acid & $18: 2 \omega-6$ & - & $\downarrow \downarrow$ & $(\uparrow)$ & $18: 2 \omega-6>10 \%$ energi \\
\hline PUFA $(\omega-3)$ & & & & & $\uparrow$ LDL jika LDL \\
- a-Linolenic acid & $18: 3 \omega-3$ & $\downarrow \downarrow$ & $(\uparrow)$ & $(\downarrow)$ & serum awal tinggi \\
- Eicosapentaenoic acid & $20: 5 \omega-3$ & $\downarrow \downarrow$ & $(\uparrow)$ & $(\downarrow)$ & $\downarrow$ HDL jika dikonsum-si \\
- Docosahexaenoic acid & $22: 5 \omega-3$ & $\downarrow \downarrow$ & $(\uparrow)$ & $(\downarrow)$ & dalam jumlah besar \\
\hline Sumb Mant 8 Stewt $(2007)$ & & & &
\end{tabular}

Sumber: Mann \& Stewart (2007)

Ratio. Konsumsi tinggi linoleic acid $(\omega-6)$ dapat menurunkan absorbs linolenic acid $(\omega-3)$ karena adanya kompetisi untuk enzim disetiap jalur metabolism, sehingga konsumsi tinggi linoleic acid akan menghambat konversi linolenic acid menjadi rantai yang lebih panjang (EPA dan DHA). Oleh karena itu perlu keseimbangan karena keduanya penting bagi membran sel. Sampai saat ini rasio keduanya masih menjadi perdebatan namun diperkirakan bahwa rasio $\omega-6 / \omega-3$ yang sesuai untuk mempertahankan kesehatan adalah 4:1, meski terdapat artikel yang menyebut kan rasio lebih tinggi. ${ }^{25}$

\section{Manfaat Seng ( $\mathrm{Zn})$ dan Tembaga $(\mathrm{Cu})$ Bagi Kesehatan}

Zat gizi $\mathrm{Zn}$ dan $\mathrm{Cu}$ berikatan dengan enzim antioksi dan superoksida dismutase (SOD). Keberadaan $\mathrm{Zn}$ dan $\mathrm{Cu}$ sangat bermanfaat untuk meningkatkan kinerja SOD, yaitu suatu enzim yang ada di dalam ekstraselular dan sitosol yang fungsinya untuk memindahkan radikal superoksida di dalam ekstraselular dan sitosol menjadi bentuk yang tidak berbahaya. Radikal superoksida tersebut dapat menyebabkan kerusakan peroksidasi pada komponen phospholipid dan membran sel. Dengan kata lain tanpa SOD, radikal superoksida dapat membuat kerusakan radikal hidroksil yang lebih parah yang membahayakan 
ikatan rangkap lemak tidak jenuh di dalam membran sel, asam lemak dan sel lain. Fungsi SOD adalah sebagai pertahanan pertama terhadap radikal bebas atau memberikan efek perlindungan terhadap terjadinya radikal bebas dalam tubuh. ${ }^{23}$

Meskipun $\mathrm{Zn}$ dan $\mathrm{Cu}$ dapat diperoleh dari hewani, namun kadar asam lemak jenuh pada hewani dapat menimbulkan efek lain sebagai pencetus radikal bebas di dalam tubuh. Kadar $\mathrm{Zn}$ dan $\mathrm{Cu}$ pada tempe yang cukup tinggi disertai dengan kadar lemak yang rendah namun mempunyai kadar asam lemak tak jenuh ganda (PUFA) dan asam lemak tak jenuh tunggal (MUFA) yang cukup, sangat bermanfaat dikonsumsi bagi individu khususnya penderita dislipidemia.

Manfaat lain $\mathrm{Zn}$ selain membantu proses antioksidan dalam tubuh adalah bahwa setidaknya 70 enzim bahkan mungkin lebih dari 200 enzim membutuhkan Zn untuk aktivitasnya di dalam tubuh, selain itu $\mathrm{Zn}$ juga sangat bermanfaat untuk imunitas tubuh. Sedangkan manfaat lain $\mathrm{Cu}$ adalah sebagai kofaktor berbagai enzim dan imunitas tubuh, ${ }^{20,} 22$

Dalam upaya mencegah penyakit degeneratif, manfaat tempe telah banyak diteliti di Indonesia. Pemberian tempe secara teratur pada penderita hiperlipidemia terbukti dapat menurunkan kadar kolesterol total, K-LDL, dan trigliserida serta sedikit meningkatkan kadar KHDL. ${ }^{23,24}$ Meskipun belum ada rekomendasi besarnya konsumsi tempe yang dianjurkan, namun jika mengacu pada jumlah maksimal konsumsi MUFA dan PUFA, yaitu kurang dari $20 \%$ dan $10 \%$ total energi, serta mempertimbangkan kebutuhan protein dari nabati yang bermanfaat bagi kesehatan, yaitu $25 \mathrm{~g} / \mathrm{hr}$, maka akan sangat baik jika setiap hari dikonsumsi 2 hingga 3 potong tempe ukuran sedang, dengan berat sekitar 100 hingga $150 \mathrm{~g}$ per hari. Dibandingkan pangan hewani, yang mengandung protein tinggi namun kandungan lemak jenuhnya juga tinggi, maka konsumsi tempe sangat bermanfaat mengingat kandungan proteinnya tinggi namun lemaknya didominasi oleh lemak tidak jenuh yang sangat bermanfaat bagi kesehatan. Kelebihan lain, tempe jauh lebih murah di bandingkan pangan hewani.

Untuk memaksimalkan manfaat tempe dan mengurangi turunnya atau rusaknya zat gizi tempe, maka disarankan tempe tidak dimasak dengan menggoreng namun pengukusan atau perebusan. Suhu tinggi selama pemasakan akan berpengaruh pada kestabilan zat gizi dan menurunkan manfaatnya. Upaya meningkatkan gerakan makan tempe perlu lebih digiatkan karena dapat menurunkan risiko dengan cara sangat murah.

\section{SIMPULAN DAN SARAN}

\section{Simpulan}

1. Proses fermentasi kedelai menyebabkan tempe mempunyai kadar asam lemak bebas atau asam lemak esensial yang jauh lebih tinggi dibanding kedelai.

2. Asam lemak esensial utama pada tempe adalah linoleic acid, oleic acid dan linolenic acid, yang sangat bermanfaat bagi kesehatan

3. Tempe juga mengandung $\mathrm{Zn}$ dan $\mathrm{Cu}$ yang sangat dibutuhkan oleh SOD untuk pertahanan pertama tubuh terhadap radikal bebas

4. Mengonsumsi tempe akan mendapatkan manfaat memperbaiki profil lipid sekaligus mencegah radikal bebas dengan biaya yang sangat terjangkau

5. Untuk mencegah terjadinya penyakit degeneratif, maka sebaiknya tempe dikonsumsi minimal 3 potong ukuran sedang per hari. Pemasakan yang baik seperti pengukusan atau perebusan sangat dianjurkan untuk tetap menjaga kandungan zat gizi dan komponen aktif tempe.

\section{Saran}

1. Mensosialisasikan gerakan makan tempe di masyarakat untuk semua lapisan di masyarakat

2. Meningkatkan pengetahuan masyarakat tentang kandungan zat gizi dan manfaat tempe bagai kesehatan serta pemasakan tempe yang baik untuk tetap mempertahankan zat gizinya.

\section{RUJUKAN}

1. Erdman Jr, J., Badger, T., Lampe,J., Setchell, K, K and Messine, M. Not soy products are created equal: caution needed in interpretation of research results. The Journal of Nutrition,2004;134:S1229-S1233. 
2. Djanuwardi, Bambang dan Chrisman Silitonga. Pattern of tempe consumption. Dalam:The complete handbook of tempe. The unique fermented soyfood of Indonesia. S.I: The American Soybean Association, 1997.

3. Badan litbang Kesehatan. Laporan Hasil Riset Kesehatan Dasar (RISKESDAS). Jakarta: Badan Penelitian dan Pengembangan Kesehatan, Departemen Kesehatan RI, 2007

4. AOAC. Dalam: Panduan Analisa. Laboratorium Terpadu Institut Pertanian. Bogor: s.n, s.a.

5. Persatuan Ahli Gizi Indonesia. Tabel komposisi pangan Indonesia. Jakarta: PERSAGI, 2009

6. Pawiroharsono S. Prospect of Tempe as Functional Food. Reinventing The Hidden Miracle of Tempe. Jakarta:Indonesia Tempe Foundation, 1997.

7. Ghozali DS. Pengaruh diet tempe terhadap kesembuhan luka pada tikus diabetes yang diinduksi streptozotocin (STZ) Skripsi. Bogor: Program studi GMSK, Faperta, Institut Pertanian Bogor, 2008.

8. Agranoff $\mathrm{J}$ and $P$ Markham. Fatty acid components of tempe (and tapeh). In: Reinventing the hidden miracle of tempe. Proceeding International Tempe Symposium July 13-15 1997, p 205-210. Jakarta: Indonesian Tempe Foundation, 1997.

9. Bisping B, L Hering, U Baumann, I denter, $S$ Keuth and HJ Rehm. Tempe fermentation: some aspects of formation of $\mathrm{y}$-linolenic acid, proteases and vitamins. Bvotech. Ad. 1993,11:481-493.

10. Wagenknecht A C, L. R. Mattick, L. M. Lewin, D.B Hand and K.H. Steinkraus. Changes in Soybean Lipids During Tempeh Fermentation. Presented at the Twentieth Annual Meeting of the Institute of Food Technologists. San Francisco: s.n, 1960.

11. Murata $\mathrm{K}, \mathrm{H}$ lkehata and $\mathrm{T}$ Miyamoto. Studies on the nutritional value of tempeh. J Food Science 1967, 32:580-586.

12. Wang $H L, E W$ Swain, $L L$ Wallen and $C$ W Hesseltine. Free Fatty Acids Identified as Antitryptic Factor in Soybeans
Fermented by Rhizopus oligosporus. J. Nutr 1975,105: 1351-1355.

13. De Reu JC, Ramdaras D, Rombouts FM and Nout MJR. Changes in soybean lipid during tempe fermentation. Food Chem 1994, 50(2):171-175.

14. Hering LB, Bisping and H.J. Rehm. Fatty acid composition during tempe fermentation. Dalam: Hermana, Mien K Mahmud dan Darwin Karyadi (penyunting) Second Asian Symposium on Non-Salted Soybean Fermentation February 13-15th. Bogor: Puslitbang Gizi Depkes RI,1990.

15. Hermana, Mien Mahmud, Darwin Karyadi.. Composition and nutritional value of tempe: its role in the improvement of the nutritional value of food. In: The complete handbook of tempe. Bogor: The American Soybean Association, 1999.

16. Stahl $H D$ and $R J$ Sims. Tempeh OilAntioxidant(?). JAOCS 1985. 63(4).

17. Sudarmadji $S$ and $P$ Markakis. Lipid and other changes occurring during the fermentation and frying of tempeh. Fd. Chem 1978:3.

18. Moeljopawiro S, ML Fields and D Gordon. Bioavailability of zinc in fermented soybeans. Journal of Food Science 53 (2):460-463.

19. Leonard V P. Linda H C and Jean Y Liu. Antioxidant potential of tempeh as compared to tocopherol. Journal of Food Science 1988; 36:798-799

20. Mann, Jim and A. Stewart Truswell (ed). Essentials of human nutrition (Third edition). London: Oxford University Press, 2007.

21. Schlenker, ED and Sara Long. Williams'Essentials of Nutrition and diet therapy, Ninth Edition. S.l: Mosby Elsevier, 2007.

22. Gropper SS, Jack L Smith, James L. Groff. Advanced nutrition and human metabolism, fourth edition. USA: Thomson Wadsworth, 2005.

23. Arbai, Arsiniati MB. Efek normolitik "tempe A5" dan "tempe" terhadap profil lipid penderita dislipidemia (Disertasi). Surabaya: Program Pascasarjana, UNAIR, 1994.

24. Sugyarto. Pengaruh tempe kedele terhadap profil lipid penderita-penderita hiperkolesterolemia yang berobat di 
bagian ilmu penyakit dalam FK UI/RSCM Jakarta. Tesis. Jakarta: Pascasarjana, UI, 1990.

25. Simopoulos A G and L G Cleland (ed). Omega-6/Omega-3 essential fatty acid ratio: The scientific evidence. World review of nutrition and dietetics edition 2003, vol 92. 